\title{
Damage and recovery of four Philippine corals from short-term sediment burial
}

\author{
Ineke Wesseling ${ }^{1}$, André J. Uychiaoco ${ }^{2}$, Porfirio M. Aliño ${ }^{2}$, Therese Aurin ${ }^{2}$, \\ Jan E. Vermaat ${ }^{1, *}$ \\ ${ }^{1}$ Department of Environmental Science and Water Resources, International Institute for Inirastructural, \\ Hydraulic and Environmental Engineering (IHE), PO Box 3015, 2601 DA Delft, The Netherlands \\ ${ }^{2}$ Marine Science Institute, University of The Philippines, Diliman 1101, Quezon City, The Philippines
}

\begin{abstract}
Recovery of corals after full burial with littoral sediment $(16 \%$ silt, $46 \%$ fine sand and $38 \%$ coarse sand; $28 \% \mathrm{CaCO}_{3}$ ) was monitored in 2 field experiments at the reefs off Lucero, Bolinao (Pangasinan, NW Philippines), from April to May 1996. In the first experiment at $2 \mathrm{~m}$ depth, Porites was buried for $0,6,20$ and $68 \mathrm{~h}$; a second experiment was done at $5 \mathrm{~m}$ depth and 4 common taxa (Porites, Galaxea, Heliopora and Acropora) were buried for $20 \mathrm{~h}$. At $2 \mathrm{~m}$ depth, Porites was not affected by $6 \mathrm{~h}$ burial compared to the controls that were not buried. Increasing burial time had increasingly more serious effects. Burial for $20 \mathrm{~h}$ resulted in increased discoloration of the coral tissue. After $68 \mathrm{~h}$ of burial, up to $90 \%$ of the tissue bleached in the first days. About $50 \%$ of this tissue disappeared subsequently and bare coral skeleton became exposed or were covered with algae. After a few weeks, however, recovery took place: the bare areas were recolonized from surrounding surviving tissue or from highly retracted polyps in the affected area. In the corals that had been buried for $20 \mathrm{~h}$ no more significant differences from the controls were observed after $3 \mathrm{wk}$. For those that were buried for $68 \mathrm{~h}$, this was the case after $4 \mathrm{wk}$. At $5 \mathrm{~m}$ depth, all Acropora died after the $20 \mathrm{~h}$ burial treatment, but the other taxa recovered in a comparable way to the Porites in the first experiment at $2 \mathrm{~m}$ depth. It is concluded that complete burial will cause considerable whole-colony mortality in at least Acropora, and thus may result in a permanent loss of coral taxa from reefs that are subject to such intense sedimentation events. Less sensitive taxa incur substantial damage but significant recovery was observed after a month.
\end{abstract}

KEY WORDS: Siltation - Partial mortality - Tissue necrosis - Bleaching - Porites - Acropora - Galaxea Heliopora. SE Asia

\section{INTRODUCTION}

Reef-building corals (Scleractinia) incur damage at various scales resulting from biotic and abiotic causes (Pearson 1981, Meesters et al. 1996, Connell et al. 1997, Lewis 1997). Sedimentation is cited as one of the main destructive forces for coral reefs (Pearson 1981, Hubbard 1986, McManus 1988, Hodgson 1990, Rogers 1990, Babcock \& Davies 1991). Enhanced sediment loading of coastal waters generally results from terrestrial deforestation (McManus 1988, Hodgson 1990) or marine construction works and dredging (Rogers 1990, Brown 1997). Sediment is deposited on coral reefs

\footnotetext{
"Addressee for correspondence. E-mail: jev@ihe.nl
}

in large quantities after extreme river discharges or typhoons (Hubbard 1986, Rogers 1990, Aronson et al. 1994, Riegl 1995, Nowlis et al. 1997).

Excessive sedimentation may lead to full burial, and several examples of burial have been reported from different areas in the world (Caribbean: Hubbard 1986, Rogers 1990, MacIntyre et al. 1994, Nowlis et al. 1997; SE Asia: McManus 1988). Existing literature on the effects of such burial and on the recovery potential for and time scales of coral regeneration describes variable results: some taxa reportedly die after a few hours of burial (Thompson 1980, Rogers 1990), while Rice \& Hunter (1992) stated that $7 \mathrm{~d}$ of burial caused $50 \%$ mortality in the least tolerant species they tested. The latter authors only recorded whole-colony mortality. Nowlis et al. (1997) found that 30 to $55 \%$ of a 
reef was covered by terrestrial mud 1 mo after a severe typhoon had hit St. Lucia. This mud cover was reduced to $15-20 \%$ in $3 \mathrm{mo}$. Hence, relevant time scales for the burial itself as well as for the responses vary between hours and months

Our purpose was to include intermediate stages of tissue degradation and to assess (1) the effects of complete but comparatively short-term burial treatments of different duration (hours to days) on colonies of $1 \mathrm{com}$ mon taxon, Porites, (2) the effects of short-term $(20 \mathrm{~h})$ burial on 4 common SE Asian coral genera (Acropora, Galaxea, Heliopora, Porites), and (3) the potential for post-burial recovery at intermediate time scales (weeks)

\section{MATERIAL AND METHODS}

Coral colonies were buried and observed for damage and recovery in 2 experiments off Lucero village, Bolinao, province of Pangasinan (NW Philippines): one on the reef flat ( $2 \mathrm{~m}$ depth, $\left.16^{\circ} 23.23^{\prime} \mathrm{N}, 119^{\circ} 54.41^{\prime} \mathrm{E}\right)$ and one on the adjacent deeper spur and groove zone ( $5 \mathrm{~m}$ depth, $16^{\circ} 25.17^{\prime} \mathrm{N}, 119^{\circ} 53.87^{\prime} \mathrm{E}$ ). The experiments were conducted from mid-April to late May 1996 (dry season). The sediment was collected near shore from the channel between the reef and the Catubig river mouth $\left(16^{\circ} 22.99^{\prime} \mathrm{N}, 119^{\circ} 54.85^{\prime} \mathrm{E}\right)$. It was composed of $16 \%$ silt $(<63 \mu \mathrm{m}), 46 \%$ fine sand ( 63 to $260 \mu \mathrm{m})$ and $38 \%$ coarse sand (>260 $\mu \mathrm{m}$ ), and the dry sediment contained $28 \% \mathrm{CaCO}_{3}$. This carbonate content suggests that it is a local mixture of marine and terrestrial material since sediments of the overall Bolinao siltation gradient vary from $6 \%$ carbonate at the river mouths to $93 \%$ at the reef flat (Terrados et al. 1998, KampNielsen, Wesseling \& Vermaat unpubl, data). Since the taxonomy of Philippine Porites, Acropora and Galaxea is complex (Veron 1986, Uychiaoco \& Aliño unpubl.), we have identified these taxa at the genus level only. For briefness, we will also refer to Heliopora coerulae Pallas here by its genus name. We used the following growth forms: massive Porites, branching Acropora, branching Heliopora and submassive Galaxea (as described by Veron 1986).

In the first experiment, at $2 \mathrm{~m}$ depth, 40 Porites colonies ( 4 blocks of $10 \mathrm{~m} \times 10 \mathrm{~m}$ area with 10 colonies each) were tagged and labelled, colony area was measured according to Meesters et al. (1996, 1997), and the percentage surface cover of a number of different categories of tissue condition (Table 1) was measured visually, aided by a grid. Observers crosscalibrated their evaluation of tissue condition categories. PVC rings $15 \mathrm{~cm}$ in height and $30 \mathrm{~cm}$ in diameter were placed around the colonies and pegged into the substrate. Two or three replicates within a
Table 1. Categories of coral tissue conditions used to describe the state of health of the colonies (modified from Rogers et al. 1994). All categories are expressed as percentage of colony area. The 3 categories 'bare coral skeleton' were classified as such on surface appearance. No cores were made for inspection of deep tissue withdrawal within the skeleton (as observed by e.g. Coles \& Fadladdah 1991); hence, no final conclusion could be drawn on the condition or moribundity of any remaining but invisible tissue

\begin{tabular}{|ll|}
\hline Abbreviation & \multicolumn{1}{c}{ Condition } \\
BLEA & $\begin{array}{l}\text { Bleached coral; white, with tissue remaining } \\
\text { Bare white clean coral skeleton without } \\
\text { tissue }\end{array}$ \\
BCS/TURF & $\begin{array}{l}\text { Bare coral skeleton without tissue but with } \\
\text { some algal turf grown over the skeleton }\end{array}$ \\
BCS/A & $\begin{array}{l}\text { Bare coral skeleton covered with algal turf: } \\
\text { skeleton not visible }\end{array}$ \\
DISCO & $\begin{array}{l}\text { Discolored (purple, bluish, pink, yellow, } \\
\text { light-brown) or partly bleached tissue but } \\
\text { not completely white }\end{array}$ \\
MUCUS & $\begin{array}{l}\text { Mucus coat } \\
\text { Sediment spot; small sediment-filled spot } \\
\text { or hole } \\
\text { Remaining healthy tissue (calculated by } \\
\text { summing the percentages of all other } \\
\text { categories per colony and subtracting this } \\
\text { from 100\%) }\end{array}$ \\
&
\end{tabular}

block (leading to 10 replicates in total per treatment) were randomly allocated to each of 4 burial periods: $0,6,20$ and $68 \mathrm{~h}$. The plastic rings were filled up with sediment, burying the corals to $1-5 \mathrm{~cm}$ depth, and at the end of the burial period this material was removed by careful fanning with a plastic slate. Percentage cover of each of the various health categories (Table 1) was then estimated for each colony at regular intervals during $4 \mathrm{wk}$ until the end of the dry season.

In the second experiment, at $5 \mathrm{~m}$ depth, basically the same procedure was followed. Here 5 specimens each of Porites, Acropora, Heliopora and Galaxea were buried for $20 \mathrm{~h}$. For each taxon, 2 additional colonies were monitored as blanks

Due to time constraints not all necessary observations could be made on the same day, Observation data were pooled into 7 time intervals that are indicated by the day on which most measurements were made, i.e. on the modal day. Measurements made before sediment application are considered preburial controls and pooled into time interval -1 . Observations made directly after removal of the sediment are placed in time interval 0 . Time interval 4 contains measurements from 4 to 6 d after treatment, time interval 8 from 7 to $10 \mathrm{~d}$, time interval 15 from 13 to $15 \mathrm{~d}$, time interval 19 from 19 to $23 \mathrm{~d}$ and time interval 27 from 27 to $30 \mathrm{~d}$ after treatment. 
Because repeated observations were made on the same colonies, the data are analysed with repeated measures ANOVAs for the separate effects of time and treatment (Potvin et al. 1990). Although Mauchly's sphericity test was generally significant, the HuynhFeldt Epsilon statistic did not deviate markedly from 1 (less then 25\%, Potvin et al. 1990); hence, application of a repeated measures ANOVA was justified. Only results for univariate tests are shown, but levels of significance were similar to those obtained from the multivariate tests. Subsequently, within each time interval, 1-way ANOVAs were carried out to compare differences in cover categories among treatments (Expt 1) and among species (Expt 2). Multiple comparisons among means were made with modified least significant difference tests maintaining an experimentwise error rate of $p<0.05$. Data were $\log _{10}(x+1)$-transformed when requirements for parametric tests were not met (homogeneity of variances, normal distribution). After transformation, the data from the second experiment still did not meet the requirements for parametric testing because of zero variance in some of the taxa. Therefore non-parametric Wilcoxon tests were done, maintaining the experiment-wise error rate at 0.05 . Means are presented \pm 1 standard error throughout this article.

\section{RESULTS}

In Expt 1, the factors time (repeated measures) and treatment as well as their interaction were significant for all tested cover categories (Table 2). We conclude from these ANOVAs (1) that different burial periods caused different responses in shallow water Porites, (2) that these responses changed with time, i.e. after an initial postburial response the colony surface passed through different stages, and (3) that this temporal change was different for the different treatments. This patterm is supported by the subsequent multiple comparisons (Fig. 1); for example, the average area with healthy tissue returned more rapidly to pre-burial values after short burial.

Short-term burial ( $6 \mathrm{~h}$ ) had no significant effect on the remaining percentage of healthy tissue (Fig. 1A), but more prolonged burial ( 20 and $68 \mathrm{~h}$ ) drastically reduced healthy areas on the Porites colonies. During the subsequent period, recovery took place and after a month the proportion of healthy area in these 2 treatments had approached the levels present in the controls (1-way ANOVA comparing 20 and $68 \mathrm{~h}$ burial treatments after $27 \mathrm{~d}$ with controls after $23 \mathrm{~d}$ : $\mathrm{p}=0.06$ ).

The patterns observed in the affected tissue categories (bleached, discolored, bare skeleton) differed among treatments. Generally, the corals that were only buried for 6 h showed no difference with the controls. The 20 and $68 \mathrm{~h}$ burial treatments produced different responses, particularly in the first days after burial. Porites colonies that had been buried for 20 h had a significantly higher proportion of discolored tissue in the first days after treatment. In the same period, the colonies of the $68 \mathrm{~h}$ treatment had significantly more bleached tissue (Fig. 1B, C). After 1 to 2 wk we observed large patches of bare skeleton in these previously bleached areas (Fig. 1C, D): the early maximum of $58 \pm 15 \%$ of colony area bleached was followed after $2 \mathrm{wk}$ by a maximum areal proportion of $45 \pm 15 \%$ of bare skeleton. In contrast, the discolored tissue of the $20 \mathrm{~h}$ burial recovered. Multiple comparisons of the areal proportion of bare skeleton revealed no difference between treatments after 19 and $27 \mathrm{~d}$ (Fig. 1D), which largely supports the pattern observed in the percentage live tissue (Fig. 1A)

In Expt 2, all taxa were significantly affected by the burial, but the change over time was only significant in Heliopora, probably because of the considerable scatter present in the data (Table 2, Fig. 2). For all genera the percentage healthy tissue decreased to less then $20 \%$ immediately after the treatment (Fig. 2). Within postburial observation periods, differences in the amount of healthy tissue between the control colonies and the treated colonies were always significant for Acropora ( $p<0.04$ ), but only so in the early postburial period for Heliopora and Porites, whilst Galaxea showed no sig-

Table 2. Summary of the univariate repeated measures ANOVAs on data from Expt 1 with shallow water Porites and from Expt 2 with 4 different taxa. Treatments in Expt 1 are 3 different durations of burial and a control; in Expt 2 only 1 burial period is compared with the control. Given are the levels of significance (p) for the effects of burial duration (treatment), post-burial time (repeated measures) and their interaction

\begin{tabular}{|lccc}
\hline Parameter & $\begin{array}{c}\text { Treatment } \\
\text { effect (p) }\end{array}$ & $\begin{array}{c}\text { Repeated } \\
\text { measures } \\
\text { effect }(\mathrm{p})\end{array}$ & $\begin{array}{c}\text { Interaction } \\
(\mathrm{p})\end{array}$ \\
\hline Expt 1 & & & \\
$\%$ bleached colony area (BLEA) & 0.001 & 0.000 & 0.005 \\
$\%$ discolored coral tissue (DISCO) & 0.006 & 0.000 & 0.001 \\
$\%$ bare coral skeleton with algae (BCS/A) & 0.018 & 0.007 & 0.001 \\
$\%$ healthy coral tissue (OK) & 0.000 & 0.000 & 0.000 \\
Expt 2: \% healthy tissue & & & \\
Acropora & 0.000 & 0.711 & 0.829 \\
Porites & 0.003 & 0.072 & 0.032 \\
Galaxea & 0.001 & 0.481 & 0.343 \\
Heliopora & 0.015 & 0.001 & 0.001 \\
\end{tabular}



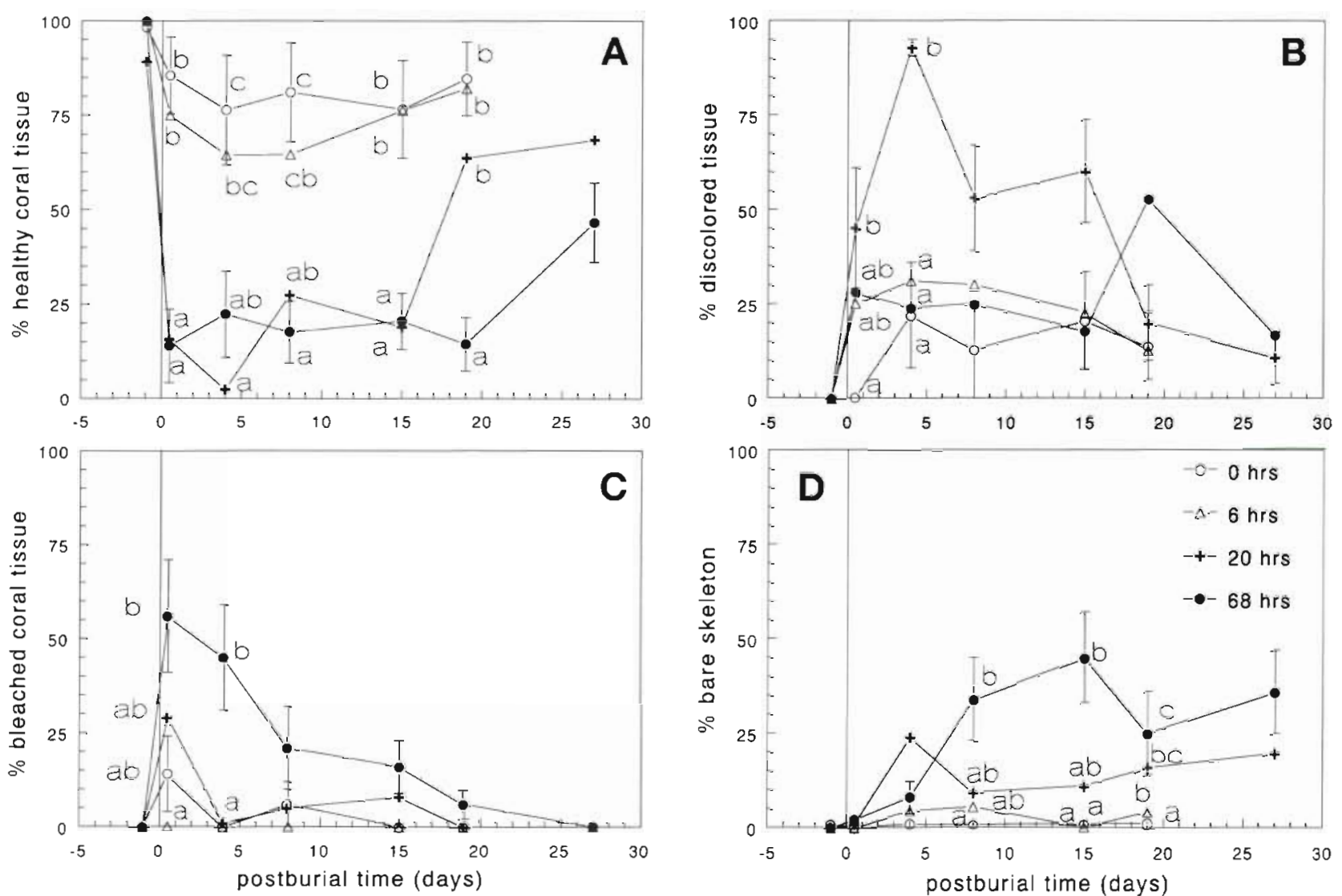

Fig. 1. Porites. Post-burial development of the percentage of coral area covered by different tissue quality categories after variable burial duration in Expt 1 (A) Percentage of remaining healthy surface area, (B) percentage of area covered by discolored tissue, (C) percentage of bleached area, (D) areal percentage of bare skeleton (summed categories BCS/A, BCS/W, BCS/TURF from Table 1). For reasons of clarity, SE bars are shown only for the control and 1 treatment. Multiple comparisons were made within each time period and different letters indicate significant differences among treatment means within such a period. Where no significant differences exist between means, no lettering is given. Replication was 10 per treatment, divided over 4 blocks

nificant burial effects ( $\mathrm{p}>0.07$ after $4 \mathrm{~d}$ post-burial). Galaxea, Heliopora and Porites started to recover within a week. Buried Acropora, however, did not recover during the period of observation and therefore probably was completely dead. No significant differences in healthy tissue were observed between the Porites at $2 \mathrm{~m}$ depth and at $5 \mathrm{~m}$ depth that were buried for $20 \mathrm{~h}$ ( $p>0.11$ for any post-burial period).

\section{DISCUSSION}

In the present experiments Porites corals survived. complete but short-term burial ( $6 \mathrm{~h}$ ) quite well. Longer periods of burial (here 20 and $68 \mathrm{~h}$ ) resulted in increased areas with discoloration, bleached tissue and bare skeleton in the first days after removal of the burying sand. Particularly the longest burial period (68 h) caused substantial areas of bleached tissue that subsequently turned into bare skeleton (more than $40 \%$ after $2 \mathrm{wk}$, Fig. 1D). However, after 3 to $4 \mathrm{wk}$, considerable recovery from the surrounding healthy coral tissue was observed, commencing a week earlier in the corals buried for $20 \mathrm{~h}$ than in those that were buried for $68 \mathrm{~h}$. Apparently bleaching is more serious than discoloration, as only bleached areas subsequently turned bare. Since we observed a sequence of bleaching, superficial tissue loss and subsequent regrowth, recovery of bare parts of colony surface was probably realised by regrowth from surrounding healthy tissue, or from re-surfacing of deeply withdrawn tissue (cf. Coles \& Faladdah 1991).

In deeper water, Porites corals responded similarly to $20 \mathrm{~h}$ burial as those from shallower water, and recovery was complete after about a month. Galaxea and Heliopora recovered over comparable time spans, but the buried Acropora colonies did not recover after an immediate and complete death. The presently applied natural sediment was a fairly coarse grained mixture of terrestrial and marine materials (cf. Thompson 1980, Rogers 1983, Rice \& Hunter 1992, Riegl 1995). This may explain the considerable survival capacity observed 


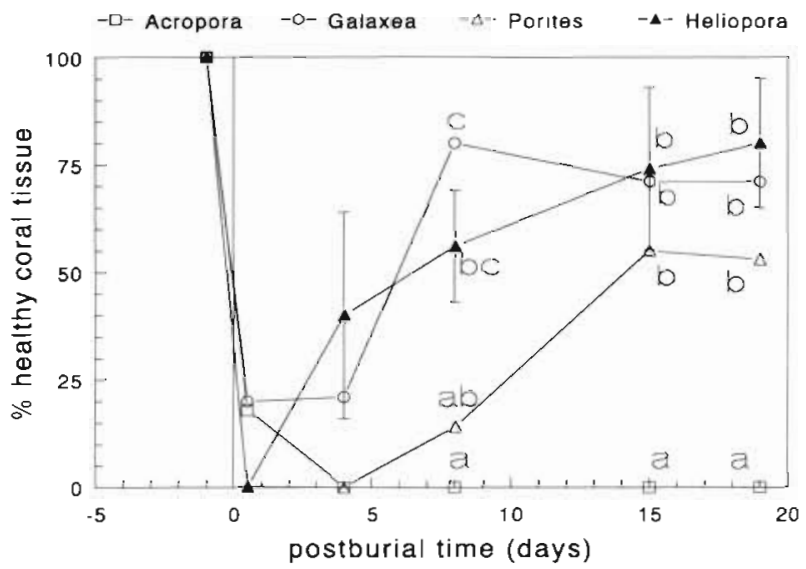

Fig. 2. Acropora, Galaxea, Heliopora and Porites. Post-burial development of the percentage of healthy coral area after $20 \mathrm{~h}$ of burial in corals in Expt 2 at $5 \mathrm{~m}$ depth. For reasons of clarity, SE bars are shown only for 1 of the coral genera. Multiple comparisons were made within each time period and different letters indicate significant differences among treatment means within such a period. Where no significant differences exist between means, no lettering is given. Replication was 5 per species, and 2 for controls

here, since Thompson (1980) reported that burial under fine drilling mud resulted in higher mortality than burial under coarse carbonate sands.

The observed among-species variation in sensitivity is in line with the findings of Thompson (1980), Rogers (1983), Rice \& Hunter (1992) and Riegl (1995). Thompson (1980) also found that Porites was comparatively insensitive to burial. We conclude that in reefs subject to intense sedimentation that includes possibly infrequent burial events, decline or absence of sensitive taxa like the presently tested Acropora is probable. Less sensitive taxa suffer less dramatically, but probably require several weeks up to months for recovery.

Acknowledgements. This paper is part of the EC STD-3 project 'Responses of Coastal Ecosystems to deforestation derived siltation in South East Asia', for practical purposes acronymed CERDS (TS3 ${ }^{\circ}$-CT94-0301). The project has been assigned to the LOICZ programme as project no. 27. We thank Wilfredo 'Al' Licuanan for advise in the field experimental design, Venus Olaivar for fabrication of field materials, Fernando 'Jhun' Castrence Jr, Rodrigo 'Lagoy' Castelo, Gabriel 'Ambing' de Guzman and Elmer 'Piriong' Dumaran for fjeld assistance and Hazel Arceo for assistance in data processing. Erik de Ruyter van Steveninck, Michiel Hootsmans and Peter van der Wateren critically read the manuscript.

\section{LITERATURE CITED}

Aronson RB, Sebens KB, Ebersole JP (1994) Hurricane Hugo's impact on Salt River submarine canyon, St Croix, US Virgin Islands. In: Ginsburg RS (ed) Proceedings of the symposium on global aspects of coral reefs: health, hazards and history Rosenstiel School of Marine and Atmospheric Science, University of Miami, p 189-195
Babcock RC, Davies P (1991) Effects of sedimentation on settlement of Acropora millepora. Coral Reefs 9:205-208

Brown BE (1997) Coral bleaching: causes and consequences. Coral Reefs 16:S129-S138

Coles SL, Fadlallah YF (1991) Reef coral survival and mortality at low temperature in the Arabian Gulf: new speciesspecific lower temperature limits. Coral Reefs 9:231-237

Connell JH, Hughes TP, Wallace CC (1997) A 30-year study of coral abundance, recruitment, and disturbance at several scales in space and time. Ecol Monogr 67:461-488

Hodgson G (1990) Sedimentation on reef corals, PhD dissertation, University of Hawaii, Honolulu

Hubbard DK (1986) Sedimentation as a control of reef development: St. Croix, U.S.V.I. Coral Reefs 5:117-125

Lewis JB (1997) Abundance, distribution and partial mortality of the massive coral Siderastrea siderea on degrading coral reefs at Barbados, West Indies. Mar Pollut Bull 34: $622-627$

MacIntyre IG, Cortes J, Glynn W (1994) Anatomy of a dying reef: Punta Islotes reef, Golfo Dulce, Costa Rica. In: Ginsburg RS (ed) Proceedings of the symposium on global aspects of coral reefs: health, hazards and history. RSMAS, Miami, p 261-266

MCManus JW (1988) Coral reefs of the ASEAN region: status and management. Ambio 17:189-193

Meesters EH, Wesseling I, Bak RPM (1996) Partial mortality in three species of reef-bullding corals and the relation with colony morphology. Bull Mar Sci 58:838-852

Meesters EH, Wesseling I, Bak RPM (1997) Coral tissue damage in six species of reef building corals: partial mortality related with depth and surface area. J Sea Res 37:131-144

Nowlis JS, Roberts CM, Smith AH, Sirrila E (1997) Humanenhanced impacts of a tropical storm on nearshore coral reefs. Ambio 26:515-521

Pearson RG (1981) Recovery and recolonization of coral reefs. Mar Ecol Prog Ser 4:105-122

Potvin CP, Lechowicz MJ, Tardif S (1990) The statistical analysis of ecophysiological response curves obtained from experiments involving repeated measures. Ecology $71: 1389-1400$

Rice SA, Hunter CL (1992) Effects of suspended sediment and burial on scleractinian corals from west central Florida patch reefs. Bull Mar Sci 51:429-442

Riegl B (1995) Effects of sand deposition on scleractinian and alcyonacean corals. Mar Biol 121:517-526

Rogers CS (1983) Sublethal and lethal effects of sediments applied to common Carribean reef corals in the field. Mar Pollut Bull 14:378-382

Rogers CS (1990) Responses of coral reefs and reef organisms to sedimentation. Mar Ecol Prog Ser 62:185-202

Rogers CS, Garrison G, Grober R, Hillis ZM, Franke M (1994) Coral reef monitoring manual for the Caribbean and Western Atlantic. National Park Service, Virgin Islands National Park

Terrados J, Duarte CM, Fortes MD, Borum J, Agawin NSR, Bach S, Thampanya U, Kamp-Nielsen L, Kenworthy WJ, Geertz-Hansen O, Vermaat JE (1998) Changes in community structure and biomass of seagrass communities along gradients of siltation in SE Asia. Estuar Coast Shelf Sci 46: $757-768$

Thompson JH (1980) Effects of drilling mud on seven species of reef-building corals as measured in field and laboratory. Report to the US Geological Survey, Department of Oceanography, Texas A\&M University, College Station, TX

Veron JEN (1986) Corals of Australia and the Indo-Pacific. The Australian Institute of Marine Science, Singapore 